\title{
Universal Civil Jurisdiction: An Option for Global Justice in Climate Change Litigation
}

\author{
Christopher Y. Nyinevi ${ }^{1}$ \\ ${ }^{1}$ Kwame Nkrumah University of Science \& Technology, Faculty of Law, Kumasi, Ghana \\ Correspondence: Christopher Y. Nyinevi, Kwame Nkrumah University of Science \& Technology, Faculty of Law, \\ P.M.B., Kumasi, Ghana. Tel: 233-262-599-019. E-mail: chrislynk05@gmail.com
}

Received: June 25, 2015 Accepted: July 14, 2015 Online Published: August 24, 2015

doi:10.5539/jpl.v8n3p135 URL: http://dx.doi.org/10.5539/jpl.v8n3p135

\begin{abstract}
The global action against climate change has been largely ineffective. In view of this, peoples and nations that are most vulnerable to the ravages of climate change (e.g., small island states) may have to develop new strategies to combat the phenomenon. Indeed, some peoples and communities already bearing the brunt of climate change are resorting to self-help measures including litigation. I argue that the doctrine of universal civil jurisdiction could be the new dynamic in the quest for international climate justice. I examine how it could potentially help small island states, and other low-lying coastal states, to hold polluting corporations liable for their contributions to climate change.
\end{abstract}

Keywords: climate change, litigation, international law, universal jurisdiction, small island states, Kyoto Protocol

\section{Introduction}

Though there still exists some skepticism, the certainty of climate change and the imminent dangers it poses to the world is now beyond the realms of speculation. In its 2007 Fourth Assessment Report, the Intergovernmental Panel on Climate Change (IPCC) (Note 1) concluded that the "[w]arming of the climate system is unequivocal, as is now evident from observations of increases in global average air and ocean temperatures, widespread melting of snow and ice, and rising global average sea level" (IPCC, 2007) (Note 2) (Emphasis added). In a place like the Maldives which is roughly 1.5 meters above sea level (CNN,2008), the sea has been observed to be rising at a level of 0.9 centimeters per annum (Bryant, 2004). At this rate, the sea could rise to a level capable of submerging the archipelago state by the end of the century (CNN, 2008; Bryant, 2004).

Notwithstanding the strong evidence of climate change and its real and imminent impact on humanity, the global response to the phenomenon has been more of rhetoric than concrete action. For instance, the Kyoto Protocol which was adopted to implement binding commitments to reduce greenhouse gases has largely failed, due, in part, to its rejection by the United States which, not only, is a major player in international relations, but also one of the largest contributors to global greenhouse gas emissions (Note 3). The stalemate in the international efforts to address climate change has left peoples and communities already being afflicted by the adverse impacts of climate change to resort to self-help measures. Litigation has been one of the major tools in this self-help agenda. The Inuit Petition lodged with the Inter-American Commission on Human Rights against the United States (Wold, Hunter \& Powers, 2009, p.430) as well as domestic cases like Massachusetts v. Environmental Protection Agency, 549 U.S. 497(2007) and Urgenda Foundation $v$ The State of the Netherlands (Ministry of Infrastructure and the Environment) (Judgment: 24 June 2015) illustrate this self-help agenda.

Litigation as a method of fighting climate change has, however, proved very problematic for obvious reasons. Both at the domestic and international levels, there have been major hurdles including how to establish legally defensible causes of action, how to single out competent defendants and how to identify effective judicial remedies. At the international level, there is the additional hurdle of finding forums in which complaints could even be lodged in the first place (Note 4).

In spite of these challenges, I argue that there is a possibility, at least conceptually, for successful climate change litigation under international law. The peculiar vulnerability of low-lying coastal countries, particularly small island states, to the impacts of climate change and the contribution of corporations to climate change combine to 
provide a unique context within which climate change litigation under international law may be successful. The theory essentially is this:

a) That corporations that fall within the category of worst emitters of greenhouse gases can be competent defendants in climate suits under international law because they are subjects of international law, i.e., corporations can be made to bear direct responsibility for climate injuries caused to other international actors through their activities.

b) That the special impacts of climate change on low-lying coastal states provide such states with a plausible cause of action as potential complainants in a climate change suit.

c) That the doctrine of universal jurisdiction by which national courts may exercise jurisdiction over certain international law offences provides competent forums within which such legal actions on climate change may be pursued. Thus, a very critical factor which would otherwise have been the missing link in this construct is supplied by the doctrine of universal jurisdiction.

The discussion is undertaken under three headings. First, I look at climate change-its causes, the contribution of multinational corporations to the phenomenon and the impact of climate change on low-lying coastal states. Next, I present the legal construct within which climate change suits under international law may be possible. Here, a look is taken at the cause of action which may be available, under international law, to small island states and other low-lying coastal states in potential climate change suits against the worst corporate emitters of green house gases. Also, the liability of corporations under international law for wrongful acts including climate injuries is discussed along with how the doctrine of universal jurisdiction can provide suitable forums for potential climate change suits. I then conclude the discussion with a look at some prudential considerations which ought to be taken into account in the pursuit of the legal construct for climate change litigation proposed in this paper.

\section{An Overview of Global Climate Change}

In 1988, the United Nations Environmental Programme (UNEP) and the World Meteorological Organization (WMO) created the Intergovernmental Panel on Climate Change (IPCC) and tasked it "to provide the world with a clear scientific view on the current state of knowledge in climate change and its potential environmental and socio-economic impacts" (IPCC Homepage). In view of this mandate, the IPCC's first task was to provide the scientific, technical, and economic basis for any policies on climate change that was to be adopted at the 1992 Earth Summit in Rio de Janeiro (Wold et al, 2009, p. 2). It is significant that Rio Earth Summit negotiated and adopted the United Nations Framework Convention on Climate Change 1992 (UNFCC). Through its research and investigations of global climatic conditions, the results of which are published in the Assessment Reports (Note 5), the IPCC has established the scientific certainty of climate change and its effects if the world goes on with business as usual.

The scientific knowledge on climate change produced by the IPCC and other independent experts reveals that the release of carbon dioxide and other greenhouses into the atmosphere is part of the natural cycle of how the atmosphere and the global climate function (Wold et al 2009, p.1). It follows, therefore, that the earth has a natural supply of greenhouse gases. This natural supply of greenhouse gases is crucial to the survival of life on earth because it traps the heat that makes the earth warm enough for the survival of humans and other living creatures. Without that natural greenhouse gas supply the "planet would [probably] be an uninhabitable, frozen wasteland" (Craig, 2012, p.8).

For a long time, at least until the industrial revolution (Wold et al, 2009, p.5), the planet had been capable of containing the amounts of carbon dioxide and other greenhouse gases released into the atmosphere through human activity and natural processes; "the amount of carbon dioxide $\left(\mathrm{CO}_{2}\right)$ and other greenhouse gases released into the atmosphere was in a rough balance with what could be stored on Earth" (Palevich, 2012, p.369). The oceans and forests acted as natural sinks absorbing the excess greenhouse gases in the atmosphere to keep the balance (Wold et al, 2009, p.5). Since the industrial revolution however, there has been a steady increase in the amount of carbon dioxide and other greenhouses gases released into the atmosphere through human activities. (Wold et al, 2009, p.5). Some of these gases can stay in the atmosphere for about half a century (Wold et al, 2009, p.5).

The effect of this development is that, currently, the amount of greenhouse gases in the atmosphere is in excess of the quantity the earth can accommodate. The capacities of the oceans and forests as natural sinks are overstretched. The excess greenhouse gases in the atmosphere have led to the phenomenon that scientists call the greenhouse effect. The greenhouse effect involves the rise in temperature that the Earth experiences on account 
of the energy trapped from the Sun by greenhouse gases - notably carbon dioxide, nitrous oxide, and methane. Currently there are six anthropogenic or man-made greenhouse gases that are subject to regulation under the UNFCC and its progeny, the Kyoto Protocol. These are carbon dioxide $\left(\mathrm{CO}_{2}\right)$, methane $\left(\mathrm{CH}_{4}\right)$, nitrous oxide $\left(\mathrm{N}_{2} \mathrm{O}\right.$ ), hydrofluorocarbons (HFCs), perfluorocarbons (PFCs), and sulfur hexafluoride (SF6) (Kyoto Protocol, 1998: Annex A). Chlorofluorocarbons, another set of greenhouse gases are regulated under the Montreal Protocol on the Substances that Deplete the Ozone Layer (Kyoto Protocol, 1998: Annex A). Carbon dioxide which, undoubtedly, is the most important of these gases accounts for about $50 \%$ of all greenhouse gases (Wold et al, 2009, p.5).

For our purposes, it is significant to mention that more than $80 \%$ of all carbon emissions come from corporations whose activities involve some form of fossil fuel burning as well as those engaged in the manufacture of cement (Wold et al, 2009, p.5; Goldenberg, 2013). Leading fossil fuel burners include corporations in the energy, manufacturing, construction and aviation industries (Kyoto Protocol, 1998: Annex A). It also significant that between 1990 and 2006 roughly 50\% of all greenhouse gas emissions for Annex I countries (Note 6) came from industrial sources (Pulles, 2007). The contribution of corporations to climate change through greenhouse gas emitting activities is therefore indisputable.

On the flip side, though, the facts are markedly different. Almost all low-lying coastal states, particularly the small island states in that category, are developing or least developing countries whose economies depend largely on subsistence agriculture and tourism. These are activities which pose no significant threat to the global climate. But while such countries are the least contributors to climate change, they are the worst sufferers of its impacts (IPCC, 2007). The wrecks of climate change are present and visible even now. The statement of Teleke P. Lauti, Tuvalu's Assistant Minister of Natural Resources and Environment at the 6th Conference of the Parties to the UNFCC (held in the year 2000 at The Hague) sums up what may ultimately be the fate of most small island states under the brunt of global climate change:

The sea is our very close neighbor. In fact, on the island where I live, Funafuti, it is possible to throw a stone from one side of the island to the other. Our islands are very low lying. When a cyclone hits us there is no place to escape. We cannot climb any mountains or move away to take refuge. It is hard to describe the effects of a cyclonic storm surge when it washes right across our islands. I would not want to wish this experience on anyone. The devastation is beyond description ... This concern is so serious for our people, that the Cabinet, [of] which I am a member, has been exploring the possibility of buying land in a near-by country, in case we become refugees to the impacts of climate change. (UNFCCC Climate Change Secretariat, 2005, p.13)

On the Maldives Islands, the sea level, as earlier noted, has been observed to be rising at $0.9 \mathrm{~cm}$ per annum (Bryant, 2004). As a defense against the rising sea levels, the Maldivian government has had to build a three-meter high wall at the cost of 63 million dollars around the capital city of Male (Bryant, 2004). But this only protects one of the about 200 inhabited islands which form the archipelago state. On the island of Kandholhudhoo, about $60 \%$ of the population had as of 2004 made plans to evacuate over a fifteen year period. Tidal waves flood their homes almost every other week (Bryant, 2004). On his inauguration in November 2008 the president of the Maldives, Mohamed Nasheed, announced a plan to relocate the entire country (CNN, 2008). The government is in talks with other states to lease lands for the relocation in order to avert the possibility of "[ending] up in refugee tents if the worst happens" (CNN, 2008).

Several other small island states face similar fates. In such low-lying coastal states, the vital infrastructure and human settlements are located few kilometers from the coast (IPCC, 2007). This puts them in grave danger of increased tidal waves caused by global climate change (IPCC, 2007). Thus, for small island states and other low-lying coastal states, climate change is not only an environmental problem; it is a serious political and security problem. If business continues as usual, some of these island nations will become desolate by the end of the century (IPCC, 2007). As nation-states, their very right to existence and self-determination is at the brink of extinction.

\section{The Construct for International Climate Change Litigation}

Having set out facts on global climate change, that is, the contribution of corporations to the phenomenon and the devastating impacts it has on the survival of low-lying coastal states especially small island nations, the question now is: On what international legal basis may a low-lying coastal state devastated, or threaten to be devastated, by the effects of climate change hold a polluting multinational corporation responsible for its contribution to the injury of that state? I suggest that an answer to this question requires, essentially, three things: 
(a) the establishment of an intelligible and plausible cause of action by the low-lying coastal state; (b) the establishment of the status of the polluting corporation as a subject of international law and hence its liability for climate change injuries; and (c) the establishment of universal jurisdiction as basis for a national court to exercise jurisdiction over the polluting corporation.

\subsection{Cause of Action: Climate Change as Violation of International Human Rights Law}

The impacts of climate change on low-lying coastal states particularly, small island states may constitute a violation of international human rights law. The customary law right to existence and self determination which has been affirmed in several international law instruments is implicated by climate change, at least, as far as small island states are concerned. The International Covenant on Civil and Political Rights 1966 declares that: "All peoples have the right to self-determination....In no case may a people be deprived of their own means of subsistence" (Art.1). (Emphasis added). Its sister convention, the International Covenant on Economic, Social and Cultural Rights 1966 uses the exact same language in article 1 thereof: "All peoples have the right to self-determination....In no case may a people be deprived of their own means of subsistence". (Emphasis added). The African Charter on Human Peoples' Rights 1981 (the African Charter) also declares the right in the following terms: "All peoples shall have the right to existence. They shall have the unquestionable and inalienable right to self- determination" (Art.20) (Emphasis added). As earlier noted, small island states are already being afflicted by the impacts of climate change. They are losing their territories. That territory is one of the most important factors in the constitution of a nation-state is an undeniable fact of international law (Note 7). In this regard, a proposition that international law should afford no remedy to peoples whose existence are threatened in this manner cannot be acceptable. Such a proposition would make nonsense of international law particularly its human rights protection regime. What makes it even more compelling to consider these climate change injuries as actionable is the fact that climate change is not a mere act of God. It is a human induced phenomenon as the scientific evidence clearly proves (IPCC, 2007). It is on this basis, that it is argued, that small island states afflicted by the impacts of anthropogenic climate change, may lawfully assert international legal claims against corporations who are no mean contributors to their injuries. A valid cause of action within this context could be founded on a violation of the customary law right to existence and self-determination.

\subsection{Corporations as Subjects of International Law}

To be a competent defendant to an international climate change suit, a polluting corporation must be shown to be a subject of the international legal system. And to qualify as a subject of international law, an entity must be capable of "possessing international rights and duties and the capacity to maintain its rights by bringing international claims" (Brownlie, 2008, p.57). That corporations, particularly multinational corporations, some of which have more resources and influence than some states (Brownlie, 2008, p.66), fit into this definition is undeniable. Two grounds could be advanced in support of this position. First, there is nothing conceptually wrong with considering corporations are subjects of international law, which by extension will be a basis for them to claim certain rights and to be equally held accountable for their actions on the international plane. Secondly, there is enough state practice to validate the conclusion that corporations are in fact subjects of international law albeit to a limited extent. Suffice it to say, however, that to be a subject of international law it is not necessary that an entity be fully possessed of all the rights and liabilities accorded to states, as "the subjects of law in any legal system are not necessarily identical in their nature or in the extent of their rights, and their nature depends upon the needs of the community" (Reparations Case, ICJ Reports, (1949) pp. 174, 178)(Emphasis added).

\subsubsection{The Conceptual Basis for the International Legal Personality of Corporations}

It is undeniable that the traditional view under international law had been that only states qualified as subjects of international law (Jessup, 1948, p.15). But like any other body of law, international law is dynamic and has been undergoing continuous development (Note 8), at least within the last sixty years or so. The end of the Second World War and the establishment of the United Nations marked the beginning of a new era for international law-it entered its modern era. The old world's view on many aspects of international law including, subjects of the international legal system has undergone significant change. The trial of the war criminals of World War II before the Nuremberg and Tokyo Tribunals marked the start of that change (Shaw, 2008, pp. 259,399 \& 400). At least since then it no longer remains the view that only states are the entities that possess rights and liabilities sufficient to qualify them as subjects of international law (Ratner, 2001, p. 473). Soon to join the group of international legal persons was the United Nations and by extension other international intergovernmental organizations. In the Reparations case, the International Court of Justice (ICJ) held that the United Nations is a "subject of international law capable of possessing international rights and duties and...has capacity to maintain 
its rights by bringing international claims" (Reparations case, p. 179). Many other entities which under the traditional view of international law could not be considered subjects of international law are now generally accepted as international legal persons with rights and liabilities as the demands of international life require (Reparations case, p. 178).

In view of these developments it is hard to see the conceptual barriers that prevent a similar status from being accorded to corporations, at least multinationals. Indeed, a presumption of any such a barrier would be rebutted by modern principles of international law. So, for instance, if properly construed, there is no reason why the standards set out in the Universal Declaration of Human Rights should not apply to corporations. The Declaration was proclaimed as "a common standard of achievement for all peoples and all nations, [and] to that end every individual and every organ of society" (Note 9). Therefore, it is not only states that have the duty to keep the "Declaration constantly in mind, and "to secure [its] universal and effective recognition and observance" (Note 10). Indeed it is a strongly shared view that "every individual" as used in the Declaration "includes juridical persons." (Henkin, 1999; Int. Council on Human Rights Policy, 2002). "Every individual and every organ of society excludes no one, no company, no market, no cyberspace. The Universal Declaration applies to them all" (Henkin, 1999). Even if the idea of construing "every individual" to include corporations is implausible, it would clearly not be farfetched to suggest that "organ" as used in the Declaration's preamble connotes an "institution or group of people or thing which performs some function" and so would encompass corporations in view of their "clear economic (and increasingly social) functions in the society" (Henkin, 1999). Some may argue that even if "organ of society" can be construed to include corporations, it still does not make a difference because the Declaration is not a binding treaty. But, this is where it becomes important to stress the customary character the Universal Declaration on Human Rights has attained, thereby making its principles universally binding as opposed to being merely persuasive (Note 11).

\subsubsection{State Practice in Support of the International Legal Personality of Corporations.}

State practice sufficiently supports the international legal personality of corporations. Through various acts including treaty making, judicial decisions and international trade and investment transactions (Note 12), the international community has come to treat corporations as subjects of international law possessed of rights and responsibilities. As noted earlier, the Nuremberg Trials were instrumental in changing the orthodox view on subjects of the international legal system. Although individuals at the end of the day emerged as the undoubted new entrants to the international legal system, corporations were not written off. In a number of the cases tried, the Tribunals found that corporations had violated international law in contributing to the atrocities of the Second World War (Note 13). For instance in United States v. Krauch (the I.G. Farben case) (Note 14) the Tribunal observed that:

With reference to the charges in the present indictment concerning [the Corporation's] activities in Poland, Norway, Alsace-Lorraine, and France, we find that the proof establishes beyond a reasonable doubt that offenses against property as defined in Control Council Law No. 10 were committed by [the corporation] Farben, and that these offenses were connected with, and an inextricable part of the German policy for occupied countries...The action of Farben and its representatives, under these circumstances, cannot be differentiated from acts of plunder or pillage committed by officers, soldiers, or public officials of the German Reich... . Such action on the part of Farben constituted a violation of the Hague Regulations [on the conduct of warfare].

That the Tribunal made these findings of law respecting the corporation is significant, because as we know the Tribunal's jurisdiction was over individuals responsible for the crimes committed in the world war and not corporations. It, thus, buttresses the earlier point that there is in fact no conceptual barrier to regarding corporations as subjects of international law.

Subsequent practices of states have continued to validate rather deny this point. In the area of international trade and investment, contracts entered into between states and corporations have an "internationalized" character. This brings the rights and obligations assumed under those agreements within the domain of international law (Note 15). Again corporations, at least those involved in foreign investments, now have access to the International Center for Settlement of Investment Disputes (ICSID) and other international arbitral bodies where they are able to maintain their rights against states by asserting claims under international law (Note 16). In Autronic AG v Switzerland (1990) 12 EHRR 485 (at para.47), the European Court of Human Rights held, that "neither Autronic AG's legal status as a limited company, nor the fact that its activities were commercial, nor the intrinsic nature of freedom of expression can deprive Autronic AG of the protection of Article 10" (Note 17). 
"The Article applies to "everyone", whether natural or legal persons" (Autronic AG, para. 47). Here, we see a corporation being accorded political rights under international law.

Also in the area of environmental law, which is our primary concern, the international community has continued to demonstrate its unequivocal posture in recognizing the legal personality of corporations, particularly as far as obligations under international environmental law are concerned. Under the 1992 Protocol to the International Convention on Civil Liability for Oil Pollution Damage, 1969, "the owner of a ship at the time of an incident" bears the responsibility for "any pollution damage caused by the ship as a result of the incident". A number of other treaties in the field of environmental law impose direct obligations on private actors including corporations for injuries caused by them to the environment and other international persons (Note 18). The 1960 Paris Convention on Third Party Liability in the Field of Nuclear Energy as amended by the 1964 and 1982 Protocols; the 1962 Brussels Convention on Liability of Operators of Nuclear Ships; the 1963 Vienna Convention on Civil Liability for Nuclear Damage; the 1971 Brussels Convention Relating to Civil Liability in the Field of Maritime Carriage of Nuclear Material; and the 1976 Convention on Civil Liability for Oil Pollution Damage Resulting from Exploration for and Exploitation of Seabed Mineral Resources are examples of such treaties under which non-state entities including corporations bear responsibility for injuries they cause to the environment and third parties.

Running through all these state practices (i.e. the environmental treaties, as well as the judicial decisions discussed earlier) - which should also sufficiently evidence opinio juris (Lauterpacht, 1958, p.380) - is one common thread: that corporations are not beyond the reach of international law, not in terms of they claiming rights lawfully due them or being held accountable for violating rules of international law. This, it is submitted, should put to rest, any doubts that corporations are subjects of international law and could therefore, in appropriate cases, be held to be possessed of certain rights and obligations. From this premise, it is also axiomatic that a polluting corporation could be held accountable for its contribution to the devastating impacts of climate change on small island states and other low-lying coastal states.

\subsection{Finding a Forum - The Role of Universal Jurisdiction of States}

The absence, at the international level, of an appropriate judicial forum for the redress of climate disputes is one of the important challenges to successful climate change litigation. The International Court of Justice's jurisdiction does not extend to non-state entities. A polluting corporation can therefore not be sued there. The Human Rights Committee, the body charged with overseeing the implementation of the International Covenant on Civil and Political Rights is also out of the question because, under the individual complaint procedure of the Covenant, the Human Rights Committee may only receive and hear complaints alleging violations of the individual rights against "state parties" to the Covenant. So here too, the utilization of the Human Rights Committee as forum for climate suits against polluting corporations is impossible because corporations are not parties to the Covenant.

It is in the face of these difficulties with finding an appropriate international forum for a climate change suit that the doctrine of universal jurisdiction comes in handy. The doctrine is founded in customary international law (Note 19). It posits that a state may exercise jurisdiction over certain violations of international law regardless of where the perpetrator or victim resides or where the crimes were committed. To put it simply, the courts of a state, under the doctrine of universal jurisdiction, may assert jurisdiction over certain violations of international law even though the offence or wrong was not committed in the territory of the state, nor are the perpetrators or victims subject to its jurisdiction (Note 20). No connecting factors are required.

Traditionally, the doctrine has been called in aid for the prosecution of some of the most serious violations of international law including piracy, slavery, genocide, crimes of aggression, war crimes, crimes against humanity, and torture when there are no other bases on which the state may assert jurisdiction. Due to its historical application to only the most serious crimes, some scholars have treated universal jurisdiction in a manner that creates doubt as to whether the doctrine is applicable in the civil context (see e.g., the Princeton Principles on Universal Jurisdiction 2001). The question of its applicability in the civil context will be answered affirmatively in the next few paragraphs. But for our present purposes, not only does this paper argue that universal jurisdiction applies in the civil context, but also that, corporations can indeed be competent defendants in climate suits under the doctrine.

\subsubsection{The Doctrine of Universal Civil Jurisdiction}

As was noted earlier, universal jurisdiction has been historically viewed as being applicable in the criminal context. It is noteworthy, however, that this view does not posit that there is any conceptual barrier to its applicability in the civil context, nor does it deny that the doctrine has ever been applied in the civil context. 
While international law is firm its command to states, it is flexible in allowing them a margin of appreciation in the implementation of those obligations. International law requires no more than that states fulfill their obligations in good faith (Note 21); the method adopted is immaterial so long that method does not conflict with other positive obligations. In this regard, the fact that criminal procedure has often been used to provide justice in cases of gross violations of international law is not itself dispositive of the issue as to what methods international law commands, or if it indeed prescribes any method at all.

The long established basis of universal jurisdiction has been that certain violations of international law are so reprehensible that they are considered to be against the whole of mankind and ought not to go unredressed. Should it then matter more the procedure by which such violations are redressed, rather than whether they are effectively redressed in fact? In any case, the assertion that universal jurisdiction has historically been applied only in the criminal context cannot be a true representation of the development of the doctrine. In the Eighteenth Century, the view indeed was that "[w]hoever offends the state, injures its rights, disturbs its tranquility, or does it a prejudice in any manner whatsoever, declares himself its enemy, and exposes himself to be justly punished for it ... [The sovereign] should avenge his wrongs, punish the aggressor, and, if possible, oblige him to make full reparations" (Note 22) (Emphasis added). Professor Eugene Kantorovich in examining the state practice on piracy, the crime around which the doctrine developed, has also observed the historical practice to be that:

Universal jurisdiction over pirates applied to both civil and criminal proceedings. When a pirate ship was captured and brought into port, where the ship and its accoutrements would be sold in a prize proceeding, those robbed by the pirates could bring suit in admiralty court requesting compensation from the proceeds of the sale. These salvage suits could be brought even when there was no nexus between the pirates, their victims, and the jurisdiction where the salvage was held. (Kontorovich, 2004, p.192) (Emphasis added)

It is clear, therefore, that in the exercise of universal jurisdiction by states, the law has long recognized that "punishment of perpetrators is only part of the task" (Stephens, 2002, p.46). A full appreciation of the doctrine, therefore, requires one to recognize that there are "two halves of the accountability equation: punishment and [the civil remedy of] compensation" (Stephens, 2002, p.46).

Again, a look at modern international law, particularly, international human rights law reveals that, international law is not so strict in its command to the extent of prescribing that only particular procedures may adopted in dealing with violations of international law. Article 8 of the Universal Declaration of Human Rights, for instance, provides that "everyone has the right to an effective remedy by the competent national tribunals for acts violating the fundamental rights granted him by the constitution or by law" (Emphasis added). Under the ICCPR, states undertake "to ensure that any person whose rights or freedoms... are violated shall have an effective remedy" and "that any person claiming such a remedy shall have his right thereto determined by competent judicial, administrative or legislative authorities, or by any other competent authority provided for by the legal system of the State" (Art. 2). Similar language is used in almost all other international human rights instruments (Note 23). These reinforce the point that the concern of international law is not necessarily with the method by which a violation is addressed, but rather the effectiveness of the remedy provided at the end of the day. There is therefore no reason why states should not apply universal jurisdiction in the civil context, if such application is effective enough to deal with the violation in question.

Another important point worth noting is that contrary to the views of some, the application of universal jurisdiction in the civil context has widespread support in the practice of states. An Amnesty International Report of 2012 reveals that most states that assert universal jurisdiction in the criminal context also "permit their courts to entertain civil claims in an action civile in criminal cases which are based on universal criminal jurisdiction" (Amnesty International, 2012, p.3). These include: Austria, Belgium, Denmark, Finland, France, Germany, Greece, Italy, Luxembourg, the Netherlands, Portugal, Spain and Sweden. Others are Argentina, Bolivia, China, Colombia, Costa Rica, Myanmar, Panama, Poland, Romania, Senegal and Venezuela. If civil claims for the recovery of compensation can be brought as part of criminal proceedings based on universal jurisdiction, then one wonders why a universal civil proceeding should be barred by international law merely because the jurisdiction is exercised independently of a criminal case.

The last point which ought to be made here is that, the distinction which some scholars seek to make between criminal and civil matters under the doctrine of universal jurisdiction is beside the point, and serves no purpose than confusing the doctrine. In the first place, the distinction between criminal offences and civil wrongs is one tenuous point which jurists are still struggling with as to where the dividing line should be drawn (Brownlie, 2008, p.300). In the United States for instance, the "Supreme Court's reasoning on issues such as the meaning of 
punishment, punitive damages, and property forfeiture has been described as an incoherent muddle" (Stephens, 2002, p. 43 \& 44). This illustrates the difficulty involved in classifying an offence as either criminal or civil. What may be considered a civil offence or process in one state may be a criminal in another. In some states crimes may only be prosecuted a public authority, in others such proceedings may be initiated and prosecuted by private individuals (Stephens, 2002, p. $43 \& 44$ ). The same difficulty is apparent in terms of the consequences attached to civil or criminal proceedings. While punitive damages are considered a civil remedy in, for instance, the United States, this may be viewed as anomalous in another jurisdiction (Note 24). In effect, no purpose is served by compartmentalizing into criminal and civil the violations of international law over which states may exercise universal jurisdiction. It is enough if the violation is sufficiently defined as one over which universal jurisdiction may be asserted, and states are left to redress those violations by the methods and remedies they consider appropriate and effective.

In concluding this sub-section, what becomes apparent is that, contrary to the beliefs of many, international law, in fact, does not frown on universal civil jurisdiction. The view that it does, is apparently informed by a misapprehension of the development of the doctrine, and the state practice in support of it. A climate change action may therefore, in appropriate cases, be brought against a polluting corporation in a national court under the doctrine of universal jurisdiction.

\subsection{The Viability of the Claim and Questions of Justiciability}

Throughout its history, the application of the doctrine of universal jurisdiction has been informed primarily by two rationales. The first is that a violation of international law over which universal jurisdiction is asserted must be, one that is, heinous; and the second, that there should be no other effective means of serving justice than by assuming jurisdiction (Stephens, 2002, p. $41 \& 42$ ). These principles, over the years, have informed the crimes over which universal jurisdiction has been exercised. If one accepts these grounds as the basis on which violations of international law should qualify for universal jurisdiction, then it seems that the ejection of islanders from their territories through climate change should be sufficient basis for the invocation of universal jurisdiction. There is no reason why human actions that cause nations to be submerged by the oceans and for millions of people to lose their lands, their means of livelihood and possibly their national identities should not be reprehensible enough to meet the heinousness prong of the test described above. Indeed if piracy whose heinousness is even doubted (Kontorovich, 2004, p.186) passes muster under the heinousness prong for the exercise of universal jurisdiction, then it becomes apparent why small island states should have a stronger case to assert that the threat to their self determination and existence is an international law violation over which universal jurisdiction can be exercised. Secondly, as it stands now, universal jurisdiction is essentially, the only means by which nations and peoples suffering this human induced catastrophe can obtain justice under international law. As has earlier been explained in this paper, there currently is no international forum within which the peoples afflicted by the impacts of climate can bring an action to obtain an effective remedy. The assertion of universal jurisdiction by national courts is therefore the only way out in this situation.

On the strength of these arguments it can be concluded that the threat climate change poses to the existence and self-determination of small island states provides a sufficient basis for them to invoke the universal jurisdiction of a national court in a climate suit.

\subsubsection{The Tests of Standing}

In most national courts, it is not sufficient that the plaintiff has a grievance. It must be sufficiently established that the grievance is a justiciable cause of action (Note 25). To be justiciable, the plaintiff's claim must not be one that merely seeks an advisory opinion from the court. Nor must it be a claim that is "too remote or speculative to warrant judicial action", or one in which "changing circumstances developing after the initiation of the lawsuit have ended the controversy" (Sullivan \& Gunther, 2010, p. 47). Above all, the plaintiff must have standing. Under this procedural requirement of standing, the plaintiff must "demonstrate that that it has suffered a concrete and particularized injury that is either actual or imminent, that the injury is fairly traceable to the defendant, and that it is likely that a favorable decision will redress that injury"(Massachusetts $v$ Environmental Protection Agency, 549 U.S 497, 517). There can be no denying that a climate action by a small island state, afflicted by climate change, will meet all these requirements. As earlier indicated, some of these island states are already bearing the brunt of changes in the global climate. Lands are being lost to rising sea levels; homes are getting destroyed and peoples are being displaced. The Maldives has had to build a wall around its capital to prevent the city from being overtaken by the sea. Deals are being negotiated to lease lands abroad to relocate some of these island states. That these would qualify as particularized injuries can hardly be disputed. Indeed in Massachusetts $v E P A$, the United States Supreme Court on a similar basis, (that "rising seas have begun to 
swallow Massachusetts' coastal lands") held that Massachusetts had standing to bring its climate change action (Note 26).

On the second element of traceability or causation, again there is likely to be no difficulty in proving that the injuries suffered by a small island state are attributable to a heavy polluting corporation. It has been held that "while a defendant [may] not be the sole entity allegedly discharging pollutant into the atmosphere that may adversely impact the Plaintiffs, the fairly traceable element does not require that a plaintiff show to a scientific certainty that the defendant's and only the defendant's emissions are the source of the threatened [or actual] harm"(Note 27). In the recent Dutch case of Urgenda Foundation v The State of the Netherlands (Ministry of Infrastructure and the Environment) (Judgment: 24 June 2015) a similar reasoning was applied by the court. The plaintiff had argued that by failing to take effective measures to reduce carbon emissions, the Netherlands was, inter alia, breaching the duty of care it owes to its current citizens and future generations to preserve the environment from the hazards of climate change. One of the defenses the government put forward was that the carbon emissions of the Netherlands were negligibly insignificant to be the basis for any liability. Rejecting this defense, the Court held that "the single circumstance that the Dutch emissions only constitute a minor contribution to global emissions does not alter the State's obligation to exercise care towards third parties" (Urgenda Case, para. 4.79). In effect, the court held that the Netherlands was vicariously responsible for the emissions of its polluting corporations. Now, recall—as previously established — that polluting corporations may independently of their host states be held liable for their internationally wrongful acts. If that is so- which in fact is the case - then there is no reason why the principle in the Urgenda case should not, with equal force, apply to a polluting corporation that is sued by an island state suffering from climate injuries. Indeed the authorities discussed so far on this point unanimously lean towards this position: that as far the ravages of climate change and other environmental harms are concerned, no contribution of any single defendant is too small to escape liability. So in the event that it is sued, it will be immaterial for a defendant corporation to argue that it could not be solely responsible for the predicament of the island state. That there are other corporations, perhaps in other countries, which are more responsible, may not be a valid defense for the corporation.

The third element of the standing requirement is also very likely to be met by a plaintiff island state. The gist of this so-called "redressability" prong is that, the dispute must be one capable of redress through a judicial proceeding, and that a "favorable decision will likely redress that injury" (Note 28). Here too, the "plaintiffs need not show that the entire problem (for instance global warming) will be cured if the Plaintiffs prevail in the action, or that the challenged action is the exclusive source of [the] harm" (Note 29). It is sufficient if the plaintiffs prove that "the risk of catastrophic harm, though remote, is nevertheless real", and that "that risk would be reduced to some extent if the petitioners received the relief they seek" (Note 30). Small islands states are suffering more than just a risk of harm; they are being afflicted by the adverse impacts of climate change even now. There is therefore no doubt that a successful climate change action which compels a corporation to either make reparations for the injuries suffered, or reduce its levels of emission will go a long way to ameliorate the plight of the suing small island state. Accordingly, this prong of the justiciability test is also likely to be met.

\section{Conclusion and some Prudential Considerations}

I have so far sought to argue, in this paper, that due to the unavailability of international judicial forums where climate change actions could be heard, it is at least conceptually possible for a national court to assume that responsibility. This I have argued will be possible within the context of a suit by a small island state or other low-lying coastal state against corporations that heavily emit greenhouse gases. Corporations, as I have sought to demonstrate, are subjects of international law and can therefore be held liable for injuries they cause to other international actors - in this case small island states which are, and will continue to be, the worst sufferers of anthropogenic climate change.

I have also argued that universal civil jurisdiction is not barred by international law, and therefore it could serve as the vehicle by which national courts may hold corporations accountable for their contributions to global climate change under international law.

Last, but not least, I have argued that the threat and actual dangers climate change poses to the existence, viability and self-determination of small island states could be a legitimate cause of action upon which a national court may assert universal jurisdiction over a corporate defendant in a climate change litigation. It has been additionally argued, under this point, that procedural requirements of standing required in national courts will pose no threat to the success of such a climate change action.

There are however some outstanding issues. Although they may not pose any threat to the legal construct I have so far sought to build, they are nonetheless worth addressing. 


\subsection{Who May Sue - Individuals or Their States?}

The right to existence and self-determination by its nature is a collective right and not an individual one. This implies that its exercise may only be done collectively or by individuals acting in a representative capacity. While it is legally conceivable, that a group of people within a state (e.g., indigenous minorities) may competently and independently of the state assert this right, as far as the climate change is concerned, it will be prudent if the state exercised the first option to bring the suit. This will avoid multiplicity of suits and ensure an organized and orderly litigation of claims. It will also act as safeguard against the situation where individual claims may be dismissed on grounds that they have not sufficiently proved that they are bringing the action in a representative capacity.

\subsection{Where to Sue - Forum of the Complainant State or That of a Foreign One?}

As sovereign states with competent judicial authorities, there is no reason why the courts of low-lying coastal states may not exercise universal jurisdiction within the context and manner described in this paper. However, prudence would dictate that a plaintiff island state should rather choose the courts of a foreign country in a climate change suit. Before looking at the prudential considerations behind this proposition though, it is important to dispel, at once, the misconception that might be created by a sovereign island state suing in the courts of another sovereign state.

The well known rule at customary law is that one sovereign may not subject another sovereign to its jurisdiction. The rule is summed up in the Latin maxim of "par in parem non habet imperium". This has been affirmed in treaties, writings of publicists and many judicial decisions including The Schooner Exchange v MacFaddon 7 Cranch 116 (1812). But it is significant to note, that while the rule obliges a state not to subject another sovereign state to its jurisdiction, the rule has never been understood to mean that a sovereign state may never waive its own right to immunity and thereby subject itself to proceedings in the forum of another state (Brownlie, 2008, p. 325). As a matter of fact, it is recognized that a state may itself institute proceedings before the courts of another state or intervene in a proceeding pending before such a court for the purposes of protecting its rights and interests (Note 31). Consequently, it would not be legally anomalous for an island state, ravaged by climate change, to institute a suit against a polluting corporation in the court of a foreign state to seek redress.

Indeed as noted from the outset, it would be prudent for the plaintiff island state to go for that option. A number of policy reasons explain this proposition. First, there are issues of credibility of the action. Even though the courts of a complainant state may be independent, politically there could be questions about whether the defendant corporation may receive a fair trial. Bad press and international criticism could mar the credibility of the process. And as far this is concerned one cannot rule out the possibility that some of these corporations could finance smear campaigns to attack the good faith of the state and its courts, and hence kill the action in the media even before it sees the light of day.

Secondly, almost all small island states and other low-lying coastal states are developing nations or least developing states. They have small economic powers and hence little or no clout in international politics and international public opinion. The host states of some these polluting corporations which feel that a climate change action against a corporation threatens their economic interest may employ various tactics to kill the suit. And in any case, a lot of these corporations themselves have more economic and political influence than some of the island states. They can therefore use various means to ensure that an action does not succeed. This underlines the reason why it will be better for a complainant state to submit itself to the jurisdiction of another state, preferably, a developed and climate friendly nation. That will likely prevent or at least minimize the risks associated with the small island state pursuing the action in its own national courts.

Thirdly, choosing the forum of a third country, also offers the complainant state the chance to select a country within which the defendant corporation operates, or has an office, a subsidiary or other business interest. While this is not necessary for triggering the jurisdiction of forum state (because no connecting factors are required for the assertion of universal jurisdiction), that will be important for ancillary processes such as service of the complaint and other documents, and ultimately the execution of the judgment, should the remedy claimed by the complainant state be granted. If the corporation has a presence in the forum state, it would be easier for those ancillary processes to be implemented.

It is for the foregoing reasons, that it would be prudent for a complainant to submit itself to the jurisdiction of the national court of a third state, notwithstanding that its own courts may properly assert jurisdiction. 


\subsection{What Remedies May Be Sought and How Will They Be Enforced?}

As far as remedies are concerned, both the complainant states and the national courts exercising jurisdiction could be creative about them. But for the purposes of this paper, one could think of monetary compensation. That could be useful for financing climate change mitigation and adaptation measures such as the building of sea defense walls or even leasing lands in third states to relocate populations affected by the impacts of climate change. There could also be orders directed at the company to, either alone or in negotiation with the complainant state, develop a climate change mitigation policy for the company with specific targets for emission reduction. Also, there is no reason why potential remedies cannot be in the form of a formal acknowledgement and apology by the defendant corporation for its contribution to the injury of the complainant state. Such an acknowledgement and apology may either be granted as a sole remedy or in addition to any other remedy granted by the court.

The enforcement of a remedy will invariably depend on the domestic legal procedures of the forum state and of course, also, on the cooperation of the international community if the corporation is neither hosted nor has any substantial business interests in the forum state. This is why, as earlier noted, it would be prudent for a complainant state to choose the forum of a third state in which the defendant corporation has some business interests. If the corporation has a presence in the forum state, execution of the judgment could definitely be easier.

\subsection{The Political and Diplomatic Implications}

There is no doubt that the practical application of this theory will come with problems. It may create diplomatic tensions between a complainant state and a defendant corporation's host state, especially where the host state feels that its economic interests are being threatened. Such political and diplomatic tensions would be natural reactions and cannot necessarily affect the legal validity of the action. They must, however, be managed for the sake of friendly relations among states.

In view of this, and the other practical difficulties the application of this theory would generate, it is suggested that it would be best to execute this agenda within the framework of an international agreement or memorandum of understanding (MOU). Such an MOU could, for instance, be arranged between small island states and the European Union, whereby European States agree to permit their courts to hear climate change claims brought by affected island states. The European Union is obviously the preferred choice because within the developed world, it is the block which has consistently shown a more progressive attitude to dealing with climate change. Within the framework of such an MOU, issues like service of complaints on defendants, enforcement of judgments, multiplicity of suits and all other matters which are likely to generate controversy and political tensions could be dealt with. This should also provide some uniform guidelines to courts which accept to exercise jurisdiction in climate change suits, and hopefully make the process more credible, transparent and less controversial.

\section{References}

Amnesty International. (2012). Universal Jurisdiction: The Scope of Universal Civil Jurisdiction. Retrieved from http://documents.law.yale.edu/sites/default/files/Amnesty\%20International\%20-\%20Universal\%20Jurisdicti on_\%20The $\% 20$ scope $\% 20$ of $\% 20$ universal $\% 20$ civil $\% 20$ jurisdiction $\% 20 \_\% 20$ Amnesty\%20International.pd $\mathrm{f}$

Brownlie, I. (2008). Principles of Public International Law (7th ed.). Oxford Univ. Press.

Bryant, N. (2004, July 28). Maldives: Paradise soon to be lost. BBC. Retrieved from http://news.bbc.co.uk/2/hi/south_asia/3930765.stm

CNN. (2008, November 11). Sinking Island's Nationals Seek New Home. Retrieved from http://edition.cnn.com/2008/WORLD/asiapcf/11/11/maldives.president/index.html\#cnnSTCText

Craig, J. (2012). Safeguarding Water and Food Supplies. Rosen Publ'g Group.

Goldenberg, S. (2013, November 20). Just 90 companies caused two-thirds of man-made global warming emissions. The Guardian. Trom http://www.theguardian.com/environment/2013/nov/20/90-companies-man-made-global-warming-emission s-climate-change

Greenspan, M. (1959). The Modern Law of Land Warfare. Univ. of California Press.

Henkin, L. (1999). The Global Market as Friend or Foe of Human Rights: The Universal Declaration at 50 and the Challenge of Global Markets' 25 Brooklyn J. Int'l L. 17. 
IPCC Homepage. http://www.ipcc.ch/organization/organization.shtml

IPCC. (2007). Fourth Assessment Report, The Physical Science Basis: Summary for Policymakers. Retrieved from http://www.ipcc.ch/publications_and_data/ar4/wg1/en/spmsspm-direct-observations.html

Jessup, P. (1948). A Modern Law of Nations: An Introduction. New York, The Macmillan Co.

Kontorovich, E. (2004). The Piracy Analogy: Modern Universal Jurisdiction's Hollow Foundation, 45 Harv. Int'l. L.J.183.

Lauterpacht, H. (1958). The Development of International Law by the International Court. London

Macedo, S. (Ed.). (2001). The Princeton Principles on Universal Jurisdiction. Princeton Program in Law \& Public Affairs.

Palevich, R. (2012). The Lean Sustainable Supply Chain: How to Create a Green Infrastructure with Lean Technologies. FT Press.

Politis, N. (1928). The New Aspects of International Law. Washington.

Pulles, T. (2007, July). Can Non-C02 Gas Emissions from Industrial Facilities be Included in Emission Trading? Presentation delivered at the Symposium on Non-CO2 Greenhouse Gases (NCGG-5), Wageningen. Retrieved from https://www.google.com.gh/webhp?sourceid=chrome-instant\&ion=1\&espv=2\&ie=UTF-8\#q=tinus\%20pull es $\% 2 \mathrm{c} \% 20$ can $\% 20$ non-c02\%20gas $\% 20$ emissions $\% 20$ from $\% 20$ industrial $\% 20$ facilities $\% 20 \mathrm{be} \% 20$ included $\% 20$ in $\% 20$ emission $\% 20$ trading $\% 3 \mathrm{f} \% 2 \mathrm{c}$

Ratner, S. R. (2001). Corporations and Human Rights: A Theory of Responsibility. 111 Yale L.J. 443. http://dx.doi.org/10.2307/797542

Stephens, B. (2002). Translating Filartiga: A Comparative and International Law Analysis of Domestic Remedies for International Human Rights Violations, 27 Yale J. Int'l L. 1.

Sullivan, K. M., \& Gunther, G. (2010). Constitutional Law. Foundation Press.

The International Council on Human Rights Policy. (2002). Beyond Voluntarism: Human Rights and the Developing International Obligations of Companies. Retrieved from http://papers.ssrn.com/sol3/papers.cfm?abstract_id $=1553201$

UNFCC Climate Change Secretariat. (2005). Climate Change: Small Island Developing States. Retrieved from http://unfccc.int/resource/docs/publications/cc_sids.pdf

Urgenda Foundation $v$ The State of the Netherlands (Ministry of Infrastructure and the Environment) C/09/456689 / HA ZA 13-1396 (English Translation). (Judgment: 24 June 2015). Retrieved from http://uitspraken.rechtspraak.nl/inziendocument?id=ECLI:NL:RBDHA:2015:7196

Wold, C., Hunter, D., \& Powers, M. (2009). Climate Change and the Law. LexisNexis.

\section{Notes}

Note 1. The IPCC is the body of experts created in 1988 by the United Nations Environmental Programme (UNEP) and the World Meteorological Organization (WMO) to provide the world with the needed scientific knowledge on climate change and its potential impacts on the world environment and the global socioeconomic system.

Note 2. See also The Fifth Assessment Report 2014, Summary for Policy Makers, available at $<$ https://www.ipcc.ch/pdf/assessment-report/ar5/wg1/WG1AR5_SPM_FINAL.pdf> ("Warming of the climate system is unequivocal, and since the 1950s, many of the observed changes are unprecedented over decades to millennia. The atmosphere and ocean have warmed, the amounts of snow and ice have diminished, sea level has risen, and concentrations of greenhouse gases have increased. Each of the last three decades has been successively warmer at the Earth's surface than any preceding decade since 1850.")

Note 3. The UN Framework Convention on Climate Change could only go as far producing broad (and perhaps some controversial) principles on the problem; no binding commitments to reducing climate change were adopted.

Note 4. This difficulty is explained by the fact that the International Court of Justice's jurisdiction does not extend to non-state entities. And even with states, the ICJ's jurisdiction is not compulsory; states have to agree to 
submit their dispute to the Court for resolution. It is doubtful whether any country, particularly the major greenhouse gas emitting ones, will consent to being sued in the Court. The other international forum which could possibly have been utilized in a climate change suit would have been the Human Rights Committee, the body charged with overseeing the implementation of the International Covenant on Civil and Political Rights. The Committee, under the individual complaint procedure of the Covenant, receives and hears complaints alleging violations of individual rights by state parties to the Covenant. These complaints can however be lodged only by identifiable individuals against state parties to the Covenant. So, obviously, there can be no complaints lodged with the Committee against corporations for violations of human rights, within the context of climate change because they are not even parties to the Covenant.

Note 5. The IPCC has so far issued five Assessment Reports-1990, 1995, 2001, 2007 and 2014

Note 6. Annex I countries are those developed nations and countries with "economies in transition" that are parties to the UNFCC and have undertaken special commitments to combat climate change.

Note 7. See Article 1 of the Montevideo Convention on the Rights and Duties of States 1933 which spells the criteria for statehood under international law. It is noteworthy that the criteria have become principles of customary law.

Note 8. See Politis, (1928) The New Aspects of International Law, p.31 ("Formerly the Sovereign state was an iron cage for its citizens from which they were obliged to communicate with the outside world, in a legal sense, through very close-set bars. Yielding to the logic of events the bars are beginning to open. The cage is becoming shaky and will finally collapse"); quoted in Jessup, at pp. 15, 16

Note 9. See The Preamble to the Universal Declaration.

Note 10. Same as Note 9.

Note 11. Although there are pockets of scholars who doubt the customary character of the Declaration, the overwhelming amount of state practice leads irresistibly to the conclusion that the UDHR or at least the great majority of the standards set therein have become customary law. The adoption and ratification of the ICCPR and ICESCR which sets out in binding obligations substantially the same rights are those contained in the Declaration evidences this. Many states have also adopted constitutions containing bills of rights which substantially adopt and affirm the rights set forth in the Declaration. These consistent and widespread acts of state practice over the last sixty years for which the Declaration has been in existence validate the customary status it has attained.

Note 12. See for instance Texaco $v$ Libya 53 ILR 387; also discussed in Shaw, at p. 829

Note 13. See for instance United States v. Flick, United States v. Krauch, United States v. Krupp and The Zyklon $B$ Case in all of which persons working through corporations committed and/or contributed to various atrocities in the war- digested in Steven R. Ratner, 'Corporations and Human Rights: A Theory of Responsibility', 111 YALE L.J. 443.

Note 14. Digested in Ratner at p. 473

Note 15. See Note 12 above and also Bankswitch (Ghana) Ltd v Ghana (PCA 118294) (Arbitration Award: 11 April 2014) Paragraph 11.64 -("Indeed, when a State party enters into a commercial contract with a foreign party, even in the case of a contract that names a domestic legal regime as the governing law, international law will apply to some aspects of the contract.")

Note 16. See The Convention on the Settlement of Investment Disputes between States and Nationals of Other States, 1965 (the ICSID Convention), article 25

Note 17. Article 10 of the European Convention on Fundamental Human Rights and Freedoms 1950 guarantees the freedom of expression.

Note 18. It is immaterial that the obligations imposed directly on private actors including corporations are to be enforced in national forums. Indeed states have customary law obligations to respect international law (pacta sunct servanda) and also to enforce them within their jurisdictions. That these obligations are therefore to be enforced in national forums in no way detracts from their being international obligations imposed directly on private actors including corporations.

Note 19. See $R v$ Bow Street Stipendiary Magistrate \& Ors, Ex parte Pinochet Ugarte (No.3) [1999] 2 All ER 97(HL) 177 (Lord Millet- "Every state has jurisdiction under customary international law to exercise 
extra-territorial jurisdiction in respect of international crimes which satisfy the relevant criteria"); See also Shaw: 668

Note 20. See Greenspan, M., (1959) The Modern Law of Land Warfare, p.420, ("Since each sovereign power stands in the position of a guardian of international law, and is equally interested in upholding it, any state has the legal right to try war crimes, even though the crimes have been committed against the nationals of another power and in a conflict to which that state is not a party.") quoted in Ex parte Pinochet Ugarte

Note 21. See the legal the maxim of "pacta sunt servanda".

Note 22. E. de Vattel, The Law of Nations 232, 161 discussed in Stephens, B., Translating Filartiga: A Comparative and International Law Analysis of Domestic Remedies for International Human Rights Violations' 27 Yale J. Int'l L. 1, 46

Note 23. See the African Charter, Art 1; The European Convention for the Protection of Human Rights \&Fundamental Freedoms, Art 13; Inter-American Convention On Human Rights, Art 2.

Note 24. A similar situation may be seen in anti-trust law where in spite of the process being civil in form, ends up as punitive because of the resulting sanctions.

Note 25. The paper looks at the justiciability requirements from the perspective of United States law. The US has quite strict justiciability requirements. And therefore the view is that if a case meets the justiciability requirements under US law, then there is a strong likelihood that it would also pass the justiciability tests in a good number of other jurisdictions.

Note 26. Mass. v EPA 549 U.S 497, 517

Note 27. Northwest Environmental Defense Center v. Owens Corning Corporation, 434 F.Supp. 2d 957, 967.(D. Or. 2006)

Note 28. Mass. $v$ EPA at 517

Note 29. Owens Corning Corp., at 968

Note 30. Mass. $v$ EPA at 526

Note 31. See United Nations Convention on the Jurisdictional Immunities of States and their Property 2005 (art. 8); Int'l Law Commission Draft Articles on the Jurisdictional Immunities of States and their Property 1991 (art. 8); State Immunity Act 1968 (UK), section 2.

\section{Copyrights}

Copyright for this article is retained by the author(s), with first publication rights granted to the journal.

This is an open-access article distributed under the terms and conditions of the Creative Commons Attribution license (http://creativecommons.org/licenses/by/3.0/). 